\title{
Clinical Protocols for the Isolation and Expansion of Mesenchymal Stromal Cells
}

\author{
Karen Bieback $^{\mathrm{a} *}$ Katharina Schallmoser ${ }^{\mathrm{b}, \mathrm{c} *}$ Harald Klüter $^{\mathrm{a}}$ Dirk Strunk $^{\mathrm{b}, \mathrm{d}}$ \\ a Institute for Transfusion Medicine and Immunology, Medical Faculty Mannheim, University of Heidelberg, German Red Cross Blood \\ Donor Service Baden-Württemberg - Hessen, Mannheim, Germany \\ bStem Cell Research Unit, \\ c University Clinic of Blood Group Serology and Transfusion Medicine, \\ d Department of Hematology and Stem Cell Transplantation, University Clinic of Internal Medicine, Medical University of Graz, Austria
}

\section{Key Words}

Mesenchymal stromal cells, multipotent - Clinical-scale expansion - Good Manufacturing Practice (GMP)

\section{Summary}

Multipotent mesenchymal stromal cells (MSCs) are currently exploited in numerous clinical trials to investigate their potential in immune regulation, hematopoiesis, and tissue regeneration. The low frequency of MSCs necessitates cell expansion to achieve transplantable numbers. The challenge is to assure safe and high-quality cell production. GMP(Good Manufacturing Practice)-graded cell processing such as cell preparation, culture, and manipulation is mandatory for the progress of such advanced cell therapy. This review summarizes protocols to isolate MSCs from bone marrow and adipose tissue and to expand MSCs for clinical use focussing on culture media composition as well as culture devices and assays to ensure and control quality of the final product.

\section{Introduction}

Important advances within the past half century have made bone marrow and tissue transplantation standard therapies for a variety of diseases. The promise of adult stem cell therapies

\footnotetext{
*Authors have contributed equally.
}

\section{Schlüsselwörter}

Mesenchymale Stromazellen, multipotente .

Klinisch relevante Expansion - Good Manufacturing

Practice (GMP)

\section{Zusammenfassung}

Derzeit laufen viele klinische Studien mit multipotenten mesenchymalen Stromazellen (MSCs), um deren Potenzial bei der Immunregulation, Hämatopoese und Geweberegeneration zu untersuchen. Der geringe Gehalt an MSCs macht eine Zellexpansion erforderlich, um transplantierbare Mengen zu erhalten. Die Herausforderung dabei besteht in der Gewährleistung einer sicheren und hochwertigen Zellproduktion. Eine gestaffelte Zellprozessierung (Zellpräparation, -kultivierung und -manipulation), die auf GMP(Good Manufacturing Practice)-Prinzipien basiert, ist für die Weiterentwicklung dieser hoch entwickelten Zelltherapie zwingend erforderlich. Der vorliegende Artikel gibt einen Überblick über Protokolle zur Isolierung von MSCs aus Knochenmark und adipösem Gewebe sowie zur Expansion von MSCs, mit besonderem Schwerpunkt auf die Zusammensetzung der Kulturmedien sowie die Kultivierungseinheiten und -assays, mit deren Hilfe die Qualität des Endprodukts gewährleistet und kontrolliert werden kann.

lies in immunological compatibility of autologous cells as well as in the relative ease of isolation. Accordingly, multipotent mesenchymal stromal cells (MSCs) have become intensely investigated candidates for somatic stem cell therapy [1-4]. MSCs are easily harvested from a variety of human tissues, including bone marrow (BM), adipose tissue (AT), and also fetal tissues like umbilical cord blood (CB) [5-8]. Furthermore,

\begin{tabular}{ll}
\hline KARGER & $\oplus$ 2008 S. Karger GmbH, Freiburg \\
$\begin{array}{l}\text { Fax +497614520714 } \\
\begin{array}{l}\text { E-mail Information@Karger.de } \\
\text { www.karger.com }\end{array}\end{array}$ & $\begin{array}{l}\text { Accessible online at: } \\
\text { www.karger.com/tmh }\end{array}$
\end{tabular}

www.karger.com 
they stand out due to their extensive expansion potential and their broad, mesodermal differentiation as well as their immunomodulatory capabilities [9-13]. These features have led to their clinical exploitation in numerous clinical trials (www.clinicaltrials.gov). Nevertheless, the initial frequency of MSCs is considered to be low with generally less than $0.1 \%$ of BM mononuclear cells in a newborn, which declines with age [14]. Admittedly, the minimal and maximal dose for therapeutic application has not been determined yet, but currently applied doses are in the range of $<1-5 \times 10^{6} \mathrm{MSCs} / \mathrm{kg}$ body weight [15]. This necessitates ex vivo expansion to achieve transplantable numbers. The future use of MSCs for therapeutic application may require very high absolute MSC numbers to gain appropriate cell doses $\left(>5 \times 10^{6} / \mathrm{kg}\right.$ body weight) per patient compared to in vivo experimental models with small animals [16]. It is therefore necessary to develop MSC expansion protocols that allow for the generation of up to 5-10 $\times$ $10^{8}$ MSCs from a limited starting volume of primary material. Accordingly, GMP(Good Manufacturing Practice)-graded cell processing such as cell preparation, culture, and manipulation is mandatory for the progress of such cell therapy. However, GMP-graded cell processing has a number of different points to consider compared to guidelines developed for finished drugs. This review focuses on protocols of isolation and expansion of MSCs from human BM and AT, release criteria, and potency testing assays (summarized in fig. 1).

\section{Isolation Techniques}

\section{Isolation of Bone Marrow-Derived MSCs}

Harvesting BM follows a standard procedure established for obtaining hematopoietic stem cell transplants. It is aspirated from the donor's posterior iliac crest using a Jamshidi needle into a heparin-containing syringe [17] and subsequently further processed by density gradient centrifugation, direct plating or different enrichment strategies.

Donor age and aspirate quality have been shown to influence MSC frequencies [14, 18]. Muschler et al. [19] suggested that volumes above $2 \mathrm{ml}$ would yield peripheral blood diluted samples. Numerous attempts to enrich MSCs from BM, equivalent to the use of CD34+ for processing hematopoietic stem cells, have been performed by using immunodepletion or enrichment strategies. Selection markers include STRO-1, CD49a, CD105, CD133, CD146, CD271, SSEA-4, antifibrin microbeads, aptamers, and aldehyde dehydrogenase activity [20-23]. None of these markers is capable of discriminating multipotent, highly proliferating MSCs from other less potent lineage-committed cells. Thus, common procedures for obtaining MSCs in clinical-scale numbers utilize density gradient isolation or direct plating to separate mesenchymal and hematopoietic cells by their adhesion capacities to the plastic surface.

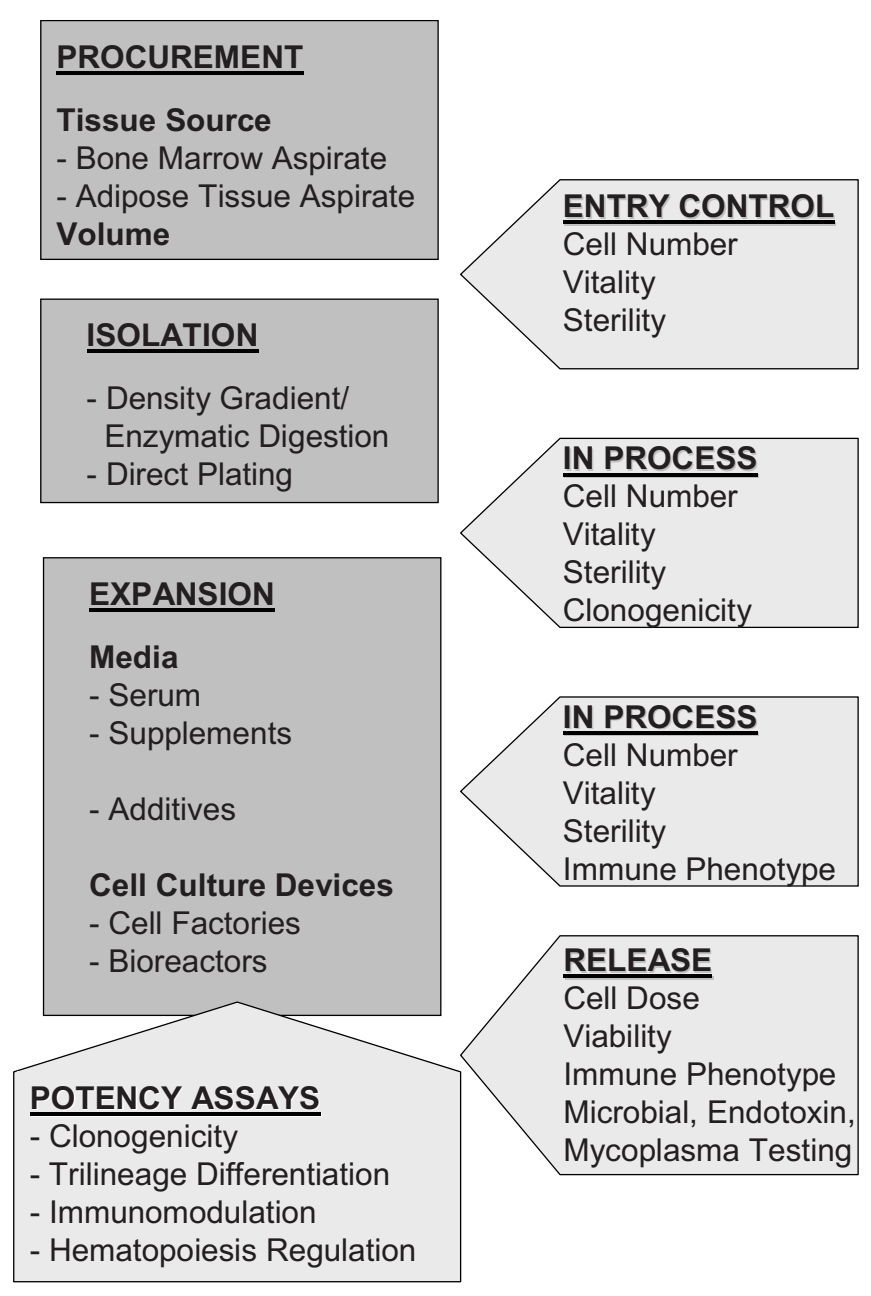

Fig. 1. Flow chart illustrating the essential processes and necessary quality assessment parameters performed in clinical protocols for isolation and expansion of multipotent mesenchymal stromal cells.

\section{Density Gradient Media}

A variety of protocols describing the isolation of MSCs from $\mathrm{BM}$ aspirates have used density gradient centrifugation to enrich the mononuclear cell fraction. Common media for this purpose include Ficoll, Percoll or dextran [24]. To the best of our knowledge most laboratories continue using Ficoll density gradient media with densities of 1,073-1,077 g/ml. A few protocols suggest better isolation efficacies by using Percoll [25]. Importantly, products used for clinical-scale manufacturing have to comply with GMP standards, but a variety of these media are now available manufactured according to both GMP and ISO (International Standard Organization) standards. Manual Ficoll gradient centrifugation can now also be replaced by using completely automated procedures. The automated Sepax cell separation system (Biosafe, Eysins, Switzerland) has yielded significantly enhanced nucleated as well as mononucleated cell recoveries when it has been compared to the manual Ficoll separation [26]. 


\section{Direct Plating}

Instead of using density gradient centrifugation, some studies performing clinical-scale isolation and expansion of MSCs follow a direct plating strategy to separate plastic adherent from nonadherent hematopoietic cells. This, however, is often accompanied by contaminating adherent myeloid cells but subsequent passaging efficiently abrogates hematopoietic contamination. Seeding densities are regarded as the most critical parameter for expanding MSCs. Most experimental and also clinical trials use high primary seeding densities of $1-2 \times 10^{5}$ BM mononuclear cells [2, 27]. Subsequent studies, however, have revealed superior expansion rates at very low to 'clonal' plating densities [28]. The challenge in clinical-scale expansion is to define a compromise between optimal expansion with maintained cell quality and practical/cost-effective issues, including cell culture plastic and medium consumption. Accordingly, plating densities of $4-22 \times 10^{3}$ bone marrow mononuclear cells (BM-MNC) $/ \mathrm{cm}^{2}$ are recommended and can yield clinical numbers of up to $9.8 \times 10^{8}$ MSCs harvested after one passage [29].

\section{Isolation of Adipose Tissue-Derived MSCs}

Plastic surgeons have been performing autologous fat grafting for filling soft tissue or contour defects for more than a century. The discovery of multipotent MSCs within this tissue has established a second major source of MSCs [30]. Besides a comparable degree of mesodermal differentiation potential, AT-derived MSCs also seem to have a high potential for angiogenesis/vasculogenesis combined with higher frequencies exceeding 100-1,000 times that of BM [31]. In most cases, lipoaspirates have been used as starting material. Liposuction procedures may yield volumes ranging from milliliters to liters of tissue [32]. Tumescent liposuction procedures involve the preinfusion of saline solutions containing anesthetics and adrenaline as vasoconstrictors. Ultrasound-assisted liposuction has been shown to compromise recovery as well as expansion capacity of MSCs [33]. For obtaining smaller volumes of tissue, machine and syringe aspiration as well as excision can be used instead [34].

Further processing steps remove cellular debris, oil, excessive blood cells and proteins as well as components of the extracellular matrix. Extensive washing generally yields satisfying purities [35]. To isolate the MSCs from the tissue, enzymatic treatment is used. Subsequently, further centrifugation steps are performed to remove the adipocyte fraction and to pellet the pre-adipocyte stromal vascular fraction. This fraction is a heterogeneous mixture of cells, including endothelial, muscle, fibroblastic and mast cells, pericytes, and preadipocytes. After the initial adherence step, all nonadherent cells are discarded by extensive washing, and the remaining adherent cells appear as fibroblastoid cells. These are cultured for about 10 days until a $60-70 \%$ confluent monolayer has de- veloped and the cells can be split to initiate the subsequent culture passage.

Although a variety of processing steps are mandatory to enrich the stromal vascular fraction, they can be implemented in a GMP-compliant protocol. To secure the process, automated devices have been developed. A 'bag within a bag' device, composed of an inner mesh and an outer sealed bag, assists to separate the tissue fraction from the contaminating fluid fraction [36]. A completely closed system, which can be used as a cell saver at the patient's bedside, performs the aspiration, washing, and concentration of the stromal vascular fraction [37]. Cells resulting from this process, however, can still only be regarded enriched for MSCs. Only a proportion of approximately 1:1,000 cells within the stromal vascular fraction will give rise to colony-forming units, equivalent to MSCs [5]. Admittedly, most studies have used specimens obtained from young and healthy subjects undergoing aesthetic liposuction. To address whether age and comorbidity may affect stem cell frequencies, DiMuzio and Tulenko correlated these factors, such as advanced age ( $>70$ years), obesity, renal failure or vascular disease, and found no significant deviation [38].

\section{MSC Expansion}

\section{Basal Media}

The best basal medium cannot yet be defined. Whereas some authors favor using alpha-MEM [28, 39, 40], others favor DMEM [41-43]. The pivotal and critical compound in MSC expansion media seems to be serum as a source of nutrients, hormones, and growth factors.

\section{Fetal Bovine Serum}

Fetal bovine serum (FBS) lot selection seems to be essential for obtaining high-quantity and -quality MSCs after ex vivo expansion [44]. Nevertheless, FBS is no longer regarded a safe supplement in clinical-scale expansion protocols as it bears a risk of transferring immunogenic xenoproteins as well as transmitting infectious agents, especially transmissible spongiform encephalopathy (TSE) [45]. Accordingly, the European Medicines Agency (EMEA) recommends that 'when manufacturers have a choice the use of materials from "non TSErelevant animal species" or non-animal origin is preferred' [46, 47]. Recently, human embryonic stem cell lines have been shown to be contaminated with an immunogenic nonhuman sialic acid [48]. N-glycolylneuraminic acid Neu5Gc is present in a variety of nutriments and has been shown to elicit $\operatorname{Ig} \mathrm{A}$, $\mathrm{IgM}$, and $\mathrm{IgG}$ antibodies. Cultures of stem cells in animal-derived culture supplements pass on this immunogenic contamination. Heiskanen et al. [49] demonstrated that despite the existence of xeno-carbohydrate Neu5Gc in MSC cultured in FBS, this contamination can be significantly decreased by transferral to human serum-containing medium but not com- 
pletely eliminated. Furthermore, FBS-derived proteins have been shown to be internalized by MSCs [50] and to be immunogenic, compromising the clinical effectiveness of MSC transplants [2,51].

\section{Human Supplements}

Although GMP-compliant FBS batches are available and used for clinical-grade manufacturing of BM-MSCs, there are serious concerns, which is paving the way for alternative human supplements. Of course, a completely chemically defined medium would be optimal for clinical-scale expansion [52], but this still has to be defined. Several working groups optimize culture media by adding human serum, plasma or platelet-derived factors. The pooled human platelet lysate (pHPL) can be obtained from buffy coat-derived platelet-rich plasma which is separated from the white and red blood cell fraction by centrifugation and is finally concentrated to at least $1 \times 10^{9}$ platelets $/ \mathrm{ml}$. The release of growth factors and mitogens stored in alpha granules of platelets may be induced by platelet activation by thrombin or by cell fragmentation during repeated freeze-thaw cycles. Among these potent mediators released from platelets are epidermal growth factor (EGF), basic fibroblast growth factor (bFGF), platelet-derived growth factors (PDGFs), transforming growth factor $\beta 1$ (TGF- $\beta 1$ ), and insulin-like growth factor (IGF). They are supposed to enhance proliferation of bone cells and chondrocytes, as well as MSCs, pointing out the essential role of platelets in processes such as wound healing and tissue repair [53-56]. However, the observed regenerative effects of platelet derivatives and their clinical outcome show extensive variations [57] due to the dependence of growth factor concentration on platelet content, preparation mode, leukocyte contamination, and mechanisms of platelet growth factor release [58]. In our own experiments, different pooled platelet lysate batches have been proven to be stable in stimulating BM-MSC proliferation and cloning efficiency as well as MSC immunophenotype (unpublished data). HPL may perhaps replace FBS in many cell culture systems that have previously been thought to strictly depend on the presence of FBS.

To support AT-derived MSC isolation and expansion we have developed and tested pooled human serum, blood type AB human serum (AB-HS), and a variety of protocols to activate the release of platelet-derived factors [59]. With large-scale clinical production in mind, we focused on pooled human blood derivatives representing at least six donors to neutralize donor-specific variations and to mimic an off-the-shelf batch which can easily be controlled according to standard blood banking procedures. Both AB-HS and thrombin-activated platelet releasate in plasma (tPRP) were superior in expanding AT-MSCs. Analyses of the transcriptome of AT-derived MSCs cultured in any of the three human supplements revealed enhanced expression of genes related to adhesion and reduced numbers of genes related to cell cycle and proliferation compared to cells cultured in FBS (manuscript in prepa- ration). Interestingly, allogeneic AB-HS-promoted expansion did not exceed FBS-driven proliferation of BM-MSCs. Some studies have announced success in isolating and expanding MSCs from BM with preserved differentiative and immunosuppressive properties using allogeneic human serum [60-62]. Others have observed reduced growth associated with advanced senescence, concluding that autologous serum would be favorable $[63,64]$.

\section{Other Additives}

The growth factor requirements of MSCs have not been elusively defined yet. PDGF, EGF, TGF- $\beta$, and IGF have been tested $[65,66]$. A variety of protocols describe adding fibroblast growth factors (FGF) to FBS-supplemented media for expanding MSCs [67]. Others indicate that factors like dexamethasone [68] or lithium, which both stimulate Wnt signalling, can enhance proliferation of MSCs [69]. The glucocorticoid dexamethasone is in common use in osteogenic differentiation protocols. Both et al. [39] have demonstrated that it not only influences osteogenesis but also enhances proliferation when continuously added. Furthermore, oxidative stress can impair MSC qualities. Enhancing the concentration of selenium/se-lenite has been shown to reduce cell damage induced by reactive oxygen species [70]. Likewise, caloric restriction mimicked in vitro by lowering the glucose content has been shown to accelerate MSC proliferation while preventing senescence [71]. Contradicting these results, telomerase-immortalized MSCs respond to higher glucose concentrations with enhanced proliferation and osteogenic differentiation [72]. Sotiropoulou et al. indicate that using Glutamax, a stabilized dipeptide form of L-glutamine, supports better cell growth compared to using L-glutamine [40].

\section{Cell Culture Devices}

\section{Cell Factories}

For clinical purposes it is necessary to produce large amounts of cells. Cell Factories provide a large growth surface by multilayered stacks in limited surface areas. They provide easy handling and low risk of contamination. Furthermore, manual operation procedures are reduced to one filling/emptying operation $[7,73,74]$.

\section{Closed System/Bioreactors}

Open culture requires expensive clean room facilities for processing. Closed systems as well as automated systems may facilitate GMP-compliant processing. Only a few protocols have been published so far. A completely closed process from cell collection to preparative processing using sterile connectors for BM stem cell expansion has been developed and validated by Gastens et al. [75]. The whole procedure was compared to the classical open cell culture method described initially. The GMP-compliant protocol involved four processing steps: i) the 
aspiration of $50 \mathrm{ml} \mathrm{BM}$ samples, ii) the density gradient isolation of mononuclear cells using an automated device, iii) the primary expansion culture in a bioreactor as well as iv) automated washing. The cellular product generated within the bioreactor included both nonadherent and adherent cells. MSCs measured both by flow cytometry and colony-forming unit fibroblasts (CFU-F) assay were expanded 320-360-fold, equivalent to the open cell culture control.

Dennis et al. [76] converted a fully automated cell production system originally designed for ex vivo production of hematopoietic progenitor cells for regenerative cells. By using their single-pass perfusion system, which very slowly but continuously replaces fresh medium, a mixed population of BM cells with osteogenic potential was expanded. By subtle changes of the culture conditions, a population enriched for osteoprogenitor cells could be generated within 12 days.

\section{Suspension Cultures/Rotary Bioreactors}

Expansion of MSCs despite their extensive proliferation potential is time consuming and thus susceptible to contamination. The emerging role of MSCs in alleviating treatment-resistant graft-versus-host disease necessitates fast expansion to meet the demand of immediate availability. Stirred suspension cultures - such as Spinner flasks in the presence of exogenously added stem cell factor (SCF) and interleukin-3 (IL-3) - expanded both fibroblastoid and osteogenic CFU to higher extents than simultaneous adherent cultures, indicating that adhesion-independent expansion is possible [77, 78]. Chen et al. [79] demonstrated that mimicking the $\mathrm{BM}$ environmental plasma perfusion rate within the rotary bioreactor with a $20 \%$ exchange of medium helped to expand MSCs but also hematopoietic progenitor cells within 8 days.

Other protocols used perfusion cultures with MSCs embedded in three-dimensional scaffolds. Perfusion yielded homogenous distribution of the MSCs and high expansion without compromising their differentiation potential [80,81].

\section{Quality Assurance, Quality Controls, and Potency Testing}

\section{In-Process Controls of ex vivo MSC Production and Criteria for Final Product Release}

\section{General Safety}

General safety testing is not mandatory for cellular therapy products according to the Food and Drug Administration (FDA; 21 CFR 610.11(g)(1)).

\section{Cell Dose}

The appropriate effective, and in contrast not harmful, dose of MSCs for various clinical indications has not yet been defined [16]. In accordance with in vivo experiments with small animals it can be assumed that a clinical dose of more than $5 \times 10^{6} \mathrm{MSCs} / \mathrm{kg}$ bodyweight of the recipient is required.

\section{Viability}

Viability of harvested MSCs can be determined by trypan blue staining or 7-amino-actinomycin D (7-AAD) exclusion. To achieve an adequate clinical effect from immediately applied MSCs and to avoid viability that is too diminished after cryopreservation, primary viability should be $>90 \%$. In exceptional cases, a lower limit of $70 \%$ viability of total harvested cells may be acceptable. In our previous large-scale expansions of MSCs, viabilities tested by 7-AAD were $95.0-97.7 \%$ and after cryopreservation $85.0-94.3 \%$ [29, 82].

\section{Immunophenotype of MSCs}

Because MSCs lack a specific marker, cells are required to be positive in $95 \%$ for CD105, CD73, and CD90 and must lack expression of CD34, CD 45, CD14 or CD11b, CD $79 \alpha$ or CD19, and human leukocyte antigen (HLA)-DR in 98\% [83].

\section{Microbiological Testing}

Sterility testing for fungal, bacterial, and mycoplasma contamination should be performed repeatedly during MSC culture. Enzyme testing as well as mycoplasma detection with polymerase chain reaction (PCR) are not yet standard methods according to the regulations of the European Pharmacopoeia or the Center for Biologics Evaluation and Research (CBER)-FDA and have to be validated compared to mycoplasma cultures. We have already introduced a validation concept for the PCR-based mycoplasma detection according to the guidelines of the European Pharmacopoeia, section 2.6.7, and validated a PCR system with the reference species Mycoplasma orale and Mycoplasma pneumoniae [84]. In addition, the MycoAlert ${ }^{\circledR}$ test (Cambrex, Verviers, Belgium) is available within less than one hour on the day of MSC harvest and has a sensitivity of $<50 \mathrm{CFU} / \mathrm{ml}$ [82]. Definitive culture results to exclude mycoplasma contamination are available within 2-3 weeks and are therefore not suitable for cell-based medicinal products (CBMP) for immediate release after production.

\section{Endotoxin and Pyrogenicity Testing}

Endotoxin is an amphipathic membrane component of Gramnegative bacteria, and its effect upon membrane structure and function of other cells may be toxic. For parenteral drugs except those administered intrathecally, the FDA guidance determines an upper limit for endotoxin of 5 endotoxin units (EU)/kg bodyweight/dose estimated by the Limulus amebocyte lysate (LAL) assay as an alternative to pyrogenicity testing. The LAL assay method can be applied to the safety evaluation of biological preparations according to existing regulations (endotoxin testing, LAL, according to the European Pharmacopoeia, section 2.6.14, and [85]). 
Fig. 2. Clonogenicity of bone marrow (BM)-derived multipotent mesenchymal stromal cells (MSCs) was tested in 5-fold serial dilution steps of heparinized BM aspiration starting from $8.0 \times 10^{4}$ to at last $6.4 \times 10^{2}$ bone marrow mononuclear cells (BM-MNC)/ $\mathrm{cm}^{2}$. BM was seeded in a-MEM, $10 \%$ pooled human platelet lysate (pHPL), and L-glutamine in $55 \mathrm{~cm}^{2}$ cell

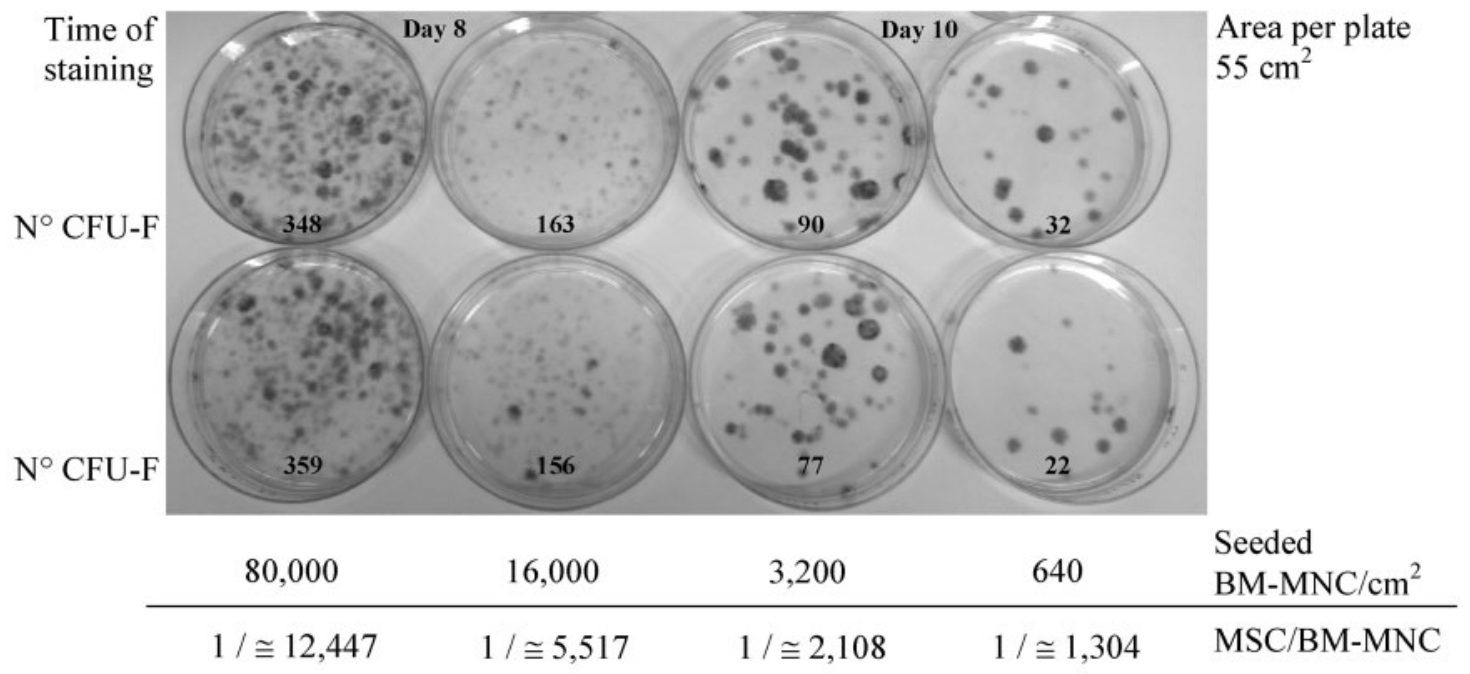
culture dishes in duplicate; nonadherent cells were removed on day 3 . Cultures starting with more than $1.5 \times 10^{4} \mathrm{BM}-\mathrm{MNC} / \mathrm{cm}^{2}$ were stopped after 8 days to get countable results. Colonies were visualized on day 8 or 10 by Harris hematoxylin staining, and those consisting of at least 50 cells were microscopically counted as colony-forming unit fibroblasts (CFU-F). Seeded BM-MNC/ $\mathrm{cm}^{2}$, culture time, CFU-F counts, and calculated MSC frequency per seeded BM-MNC are shown.

\section{Potency Assays and MSC Functionality}

\section{Clonogenicity}

The colony-forming unit (CFU) assay is a suitable tool for evaluating the self-renewal capacity of cells. Friedenstein et al. [86] were the first to describe an assay system to study fibroblast precursors in various hematopoietic cell populations (CFU-F). Analysis of the CFU-F frequency in BM aspirates necessitates adequate dilution. Probably due to a combination of minimal manipulation of the BM before seeding and low seeding densities of BM-MNC, we could observe generally higher CFU-F frequencies [29] than published previously [14]. In figure 2, representative results of seeding primary BM in serial 5-fold dilution steps of $\mathrm{BM}-\mathrm{MNC} / \mathrm{cm}^{2}$ culture area are shown. In this experiment, the calculated frequency of colonyforming MSCs per seeded BM-MNC was 1 MSC in 12,560 $\mathrm{BM}-\mathrm{MNC}$ (seeding density 80,000 BM-MNC/cm${ }^{2}$ ) and increased parallel with decreasing BM-MNC seeding density (1:1,520 at about $640 \mathrm{BM}-\mathrm{MNC} / \mathrm{cm}^{2}$ ) (fig. 2). Starting from enriched MSCs following primary culture, the adequate seeding density for CFU-F analysis ranges from 1 to $5 \mathrm{MSCs} / \mathrm{cm}^{2}[7$, 87].

\section{Osteo-, Chondro-, and Adipogenic Differentiation}

Pittenger et al. have shown that isolated human BM-derived MSCs differentiate to multiple lineages of mesenchymal tissue [43]. Furthermore, there is evidence that MSCs can also express phenotypic characteristics of endothelial, neural, and smooth muscle cells as well as skeletal myoblasts and cardiac myocyte cells [88]. The standard pathways of MSC differentiation take course along osteogenic, chondrogenic, and adi- pogenic lineages and have been elaborately reported in a large number of publications [89]. This potency assay may be performed regularly in ex vivo clinical expansion of MSCs if bone or connective tissue repair is intended.

\section{Immunomodulatory Capacities of MSCs}

Human MSCs surface molecules such as HLA-class I, Thy-1 (CD90), vascular cell adhesion molecule (VCAM, CD106), intercellular adhesion molecule-1 and -2 (ICAM-1, ICAM-2), activated leukocyte cell adhesion molecule (ALCAM, CD166), lymphocyte functional antigen-3, and various integrins indicate interaction with cognate ligands on T cells [88]. In contrast to an expected induction of $\mathrm{T}$ cell response against allogeneic MSCs, T cell alloreactivity is inhibited by MSCs in mixed lymphocyte cultures (MLC) or lymphocyte proliferation induced by mitogens, such as phytohemagglutinin (PHA) or concanavalin A $[7,12]$. Remarkably, MSCs in high concentrations (representing 10-40 MSCs per 100 responder lymphocytes) inhibit, while low MSC concentrations (0.1-1\%) may stimulate lymphocyte proliferation in MLC [90]. These findings also stress further investigations for the optimal MSC dose, e.g. in patients with graft-versus-host disease following allogeneic BM transplantation to gain the optimal immunosuppressive effect. In this case, too low numbers of transplanted MSCs could cause stimulation of lymphocyte proliferation in vivo and hence boost the graft-versus-host disease as an adverse reaction to the MSC therapy.

\section{Hematopoiesis Regulation}

Previously it has been shown that co-culturing CB-derived CD34+ cells with MSCs enhances efficiency of ex vivo expan- 
sion of hematopoietic progenitor cells (HPC) [8, 91, 92]. This in vitro regulatory effect of MSCs may contribute to therapeutic efficacy of cord blood HPC transplantation due to an increase of the primarily available low dose of HPC. Also in vivo engraftment of hematopoietic stem cells after myeloablative therapy was shown to be improved by simultaneous infusion of MSCs in the autologous as well as the allogeneic setting $[16,27]$.

\section{Conclusion}

It is obvious that there is currently a significant lack of standardization in GMP-compliant MSC manufacturing protocols as well as in defining release criteria and potency assays. Numerous activities worldwide have demonstrated significant achievements. The need to establish global standards and guidelines has been demonstrated by the evolution of hematopoietic stem cell transplantation from a highly experimental procedure to a standard therapy over the last decade. Based on the intensity of the work that is being performed, it can be anticipated that MSC therapy will follow this example within an even shorter period of time.

\section{Acknowledgements}

The authors wish to thank Lucy Smith for assistance with the manuscript preparation. This work was partially supported by a research fund of the German Federal Ministry of Education and Research (O1GN O531), by OsteoCord (LSHB-CT-2005-018999), a project commissioned by the European Community, and by an Austrian Research Foundation (FWF) grant NAN200, NanoSTEM project NAN202.

\section{References}

1 Lazarus HM, Haynesworth SE, Gerson SL, Rosenthal NS, Caplan AI: Ex vivo expansion and subsequent infusion of human bone marrow-derived stromal progenitor cells (mesenchymal progenitor cells): implications for therapeutic use. Bone Marrow Transplant 1995;16:557-564.

- 2 Horwitz EM, Gordon PL, Koo WK, Marx JC, Neel MD, McNall RY, Muul L, Hofmann T: Isolated allogeneic bone marrow-derived mesenchymal cells engraft and stimulate growth in children with osteogenesis imperfecta: implications for cell therapy of bone. Proc Natl Acad Sci U S A 2002;99:8932-8937.

3 Garcia-Olmo D, Garcia-Arranz M, Herreros D, Pascual I, Peiro C, Rodriguez-Montes JA: A phase I clinical trial of the treatment of Crohn's fistula by adipose mesenchymal stem cell transplantation. Dis Colon Rectum 2005;48:1416-1423.

4 Le Blanc K, Rasmusson I, Sundberg B, Gotherstrom C, Hassan M, Uzunel M, Ringden O: Treatment of severe acute graft-versus-host disease with third party haploidentical mesenchymal stem cells. Lancet 2004;363:1439-1441.

5 Kern S, Eichler H, Stoeve J, Kluter H, Bieback K: Comparative analysis of mesenchymal stem cells from bone marrow, umbilical cord blood, or adipose tissue. Stem Cells 2006;24:1294-1301.

6 Bieback K, Kern S, Kocaomer A, Ferlik K, Bugert $\mathrm{P}$ : Comparing mesenchymal stromal cells from different human tissues: bone marrow, adipose tissue and umbilical cord blood. Biomed Mater Eng 2008; 18(suppl 1):S71-76.

7 Bartmann C, Rohde E, Schallmoser K, Purstner P, Lanzer G, Linkesch W, Strunk D: Two steps to functional mesenchymal stromal cells for clinical application. Transfusion 2007;47:1426-1435.

8 Reinisch A, Bartmann C, Rohde E, Schallmoser K, Bjelic-Radisic V, Lanzer G, Linkesch W, Strunk D: Humanized system to propagate cord blood-derived multipotent mesenchymal stromal cells for clinical application. Regen Med 2007;2:371-382.

9 Rojewski M, Weber B, Schrezenmeier H: Phenotypic characterization of mesenchymal stem cells from various tissues. Transfus Med Hemother 2008;35: 168-184.

10 Bieback K: Basic biology of mesenchymal stem cells. Transfus Med Hemother 2008;35:151-152.
11 Schaefer R, Northoff H: Characteristics of mesenchymal stem cells - new stars in regenerative medicine or unrecognized old fellows in autologous regeneration? Transfus Med Hemother 2008;35: 154-159.

12 Bifari F, Lisi V, Mimiola E, Pasini A, Krampera M: Immune modulation by mesenchymal stem cells. Transfus Med Hemother 2008;35:194-204.

13 Gimble JM, Guilak F, Nuttall ME, Sathishkumar S, Vidal M, Bunnell BA: In vitro differentiation potential of mesenchymal stem cells. Transfus Med Hemother 2008;35:228-238.

14 Caplan AI: Adult mesenchymal stem cells for tissue engineering versus regenerative medicine. J Cell Physiol 2007;213:341-347.

15 Subbanna PK: Mesenchymal stem cells for treating GVHD: in-vivo fate and optimal dose. Med Hypotheses 2007;69:469-470.

16 Lazarus HM, Koc ON, Devine SM, Curtin P, Maziarz RT, Holland HK, Shpall EJ, McCarthy P, Atkinson K, Cooper BW, Gerson SL, Laughlin MJ, Loberiza FR Jr, Moseley AB, Bacigalupo A: Cotransplantation of HLA-identical sibling cultureexpanded mesenchymal stem cells and hematopoietic stem cells in hematologic malignancy patients. Biol Blood Marrow Transplant 2005;11:389-398.

17 Bain BJ: Bone marrow aspiration. J Clin Pathol 2001:54:657-663.

18 Stolzing A, Jones E, McGonagle D, Scutt A: Agerelated changes in human bone marrow-derived mesenchymal stem cells: consequences for cell therapies. Mech Ageing Dev 2008;129:163-173.

19 Muschler GF, Boehm C, Easley K: Aspiration to obtain osteoblast progenitor cells from human bone marrow: the influence of aspiration volume. J Bone Joint Surg Am 1997;79:1699-1709.

20 Abdallah BM, Kassem M: Human mesenchymal stem cells: from basic biology to clinical applications. Gene Ther 2008;15:109-116.

21 Guo KT, Schaefer R, Paul A, Gerber A, Ziemer G, Wendel HP: A new technique for the isolation and surface immobilization of mesenchymal stem cells from whole bone marrow using high-specific DNA aptamers. Stem Cells 2006;24:2220-2231.
22 Gentry T, Foster S, Winstead L, Deibert E, Fiordalisi M, Balber A: Simultaneous isolation of human BM hematopoietic, endothelial and mesenchymal progenitor cells by flow sorting based on aldehyde dehydrogenase activity: implications for cell therapy. Cytotherapy 2007;9:259-274.

23 Sorrentino A, Ferracin M, Castelli G, Biffoni M, Tomaselli G, Baiocchi M, Fatica A, Negrini M, Peschle C, Valtieri M: Isolation and characterization of CD146(+) multipotent mesenchymal stromal cells. Exp Hematol 2008(Epub ahead of print).

24 Fluks AJ: Three-step isolation of human blood monocytes using discontinuous density gradients of Percoll. J Immunol Methods 1981;41:225-233.

25 Lange C, Schroeder J, Stute N, Lioznov MV, Zander AR: High-potential human mesenchymal stem cells. Stem Cells Dev 2005;14:70-80.

26 Aktas M, Radke TF, Strauer BE, Wernet P, Kogler G: Separation of adult bone marrow mononuclear cells using the automated closed separation system Sepax. Cytotherapy 2008;10:203-211.

27 Koc ON, Gerson SL, Cooper BW, Dyhouse SM, Haynesworth SE, Caplan AI, Lazarus HM: Rapid hematopoietic recovery after coinfusion of autologous-blood stem cells and culture-expanded marrow mesenchymal stem cells in advanced breast cancer patients receiving high-dose chemotherapy. J Clin Oncol 2000;18:307-316.

28 Sekiya I, Larson BL, Smith JR, Pochampally R, Cui JG, Prockop DJ: Expansion of human adult stem cells from bone marrow stroma: conditions that maximize the yields of early progenitors and evaluate their quality. Stem Cells 2002;20:530-541.

29 Schallmoser K, Rohde E, Reinisch A, Bartmann C, Thaler D, Drexler C, Obenauf AC, Lanzer G, Linkesch W, Strunk D: Rapid large scale expansion of functional mesenchymal stem cells from unmanipulated bone marrow without animal serum. Tissue Eng 2008(in press).

30 Schaffler A, Buchler C: Concise review: adipose tissue-derived stromal cells - basic and clinical implications for novel cell-based therapies. Stem Cells 2007;25:818-827.

31 Moseley TA, Zhu M, Hedrick MH: Adipose-derived stem and progenitor cells as fillers in plastic and reconstructive surgery. Plast Reconstr Surg 2006;118(suppl 3):121S-128S. 
\$2 Gimble JM, Katz AJ, Bunnell BA: Adipose-derived stem cells for regenerative medicine. Circ Res 2007; 100:1249-1260.

\$3 Oedayrajsingh-Varma MJ, van Ham SM, Knippenberg M, Helder MN, Klein-Nulend J, Schouten TE, Ritt MJ, van Milligen FJ: Adipose tissue-derived mesenchymal stem cell yield and growth characteristics are affected by the tissue-harvesting procedure. Cytotherapy 2006;8:166-177.

\34 Dubois SG, Floyd EZ, Zvonic S, Kilroy G, Wu X, Carling S, Halvorsen YD, Ravussin E, Gimble JM: Isolation of human adipose-derived stem cells from biopsies and liposuction specimens. Methods Mol Biol 2008;449:69-79.

\$3 Zuk PA, Zhu M, Mizuno H, Huang J, Futrell JW, Katz AJ, Benhaim P, Lorenz HP, Hedrick MH: Multilineage cells from human adipose tissue: implications for cell-based therapies. Tissue Eng 2001;7: 211-228.

>36 Katz AJ, Hedrick MH, Llull R, Futrell JW: A novel device for the simple and efficient refinement of liposuctioned tissue. Plast Reconstr Surg 2001;107: 595-597.

37 Duckers HJ, Pinkernell K, Milstein AM, Hedrick $\mathrm{MH}$ : The Bedside Celution ${ }^{\mathrm{TM}}$ system for isolation of adipose derived regenerative cells. EuroIntervention 2006;2:395-398.

38 DiMuzio P, Tulenko T: Tissue engineering applications to vascular bypass graft development: the use of adipose-derived stem cells. J Vasc Surg 2007;45 (suppl A):A99-103.

39 Both SK, van der Muijsenberg AJ, van Blitterswijk CA, de Boer J, de Bruijn JD: A rapid and efficient method for expansion of human mesenchymal stem cells. Tissue Eng 2007;13:3-9.

40 Sotiropoulou PA, Perez SA, Salagianni M, Baxevanis CN, Papamichail M: Characterization of the optimal culture conditions for clinical scale production of human mesenchymal stem cells. Stem Cells 2006;24:462-471.

41 Bieback K, Kern S, Kluter H, Eichler H: Critical parameters for the isolation of mesenchymal stem cells from umbilical cord blood. Stem Cells 2004;22: 625-634.

-42 Jaiswal N, Haynesworth SE, Caplan AI, Bruder SP Osteogenic differentiation of purified, culture-expanded human mesenchymal stem cells in vitro. J Cell Biochem 1997;64:295-312.

43 Pittenger MF, Mackay AM, Beck SC, Jaiswal RK, Douglas R, Mosca JD, Moorman MA, Simonetti DW, Craig S, Marshak DR: Multilineage potential of adult human mesenchymal stem cells. Science 1999;284:143-147.

44 Caterson EJ, Nesti LJ, Danielson KG, Tuan RS: Human marrow-derived mesenchymal progenitor cells: isolation, culture expansion, and analysis of differentiation. Mol Biotechnol 2002;20:245-256.

45 Asher DM: Bovine sera used in the manufacture of biologicals: current concerns and policies of the U.S. Food and Drug Administration regarding the transmissible spongiform encephalopathies. Dev Biol Stand 1999;99:41-44.

46 Note for guidance on the use of bovine serum in the manufacture of human biological medicinal products. EMEA CPMP/BWP/1793/02;2003.

47 Note for guidance on minimising the risk of transmitting animal spongiform encephalopathy agents via human and veterinary medicinal products. EMEA/410/01 rev2;2004.

48 Martin MJ, Muotri A, Gage F, Varki A: Human embryonic stem cells express an immunogenic nonhuman sialic acid. Nat Med 2005;11:228-232.
49 Heiskanen A, Satomaa T, Tiitinen S, Laitinen A, Mannelin S, Impola U, Mikkola M, Olsson C, Miller-Podraza H, Blomqvist M, Olonen A, Salo H, Lehenkari P, Tuuri T, Otonkoski T, Natunen J, Saarinen J, Laine J: N-glycolylneuraminic acid xenoantigen contamination of human embryonic and mesenchymal stem cells is substantially reversible. Stem Cells 2007;25:197-202.

50 Spees JL, Gregory CA, Singh H, Tucker HA, Peister A, Lynch PJ, Hsu SC, Smith J, Prockop DJ: Internalized antigens must be removed to prepare hypoimmunogenic mesenchymal stem cells for cell and gene therapy. Mol Ther 2004;9:747-756

51 Sundin M, Ringden O, Sundberg B, Nava S, Gotherstrom C, Le Blanc K: No alloantibodies against mesenchymal stromal cells, but presence of antifetal calf serum antibodies, after transplantation in allogeneic hematopoietic stem cell recipients. Haematologica 2007;92:1208-1215.

52 Mannello F, Tonti GA: Concise review: no breakthroughs for human mesenchymal and embryonic stem cell culture: conditioned medium, feeder layer, or feeder-free; medium with fetal calf serum, human serum, or enriched plasma; serum-free, serum replacement nonconditioned medium, or ad hoc formula? All that glitters is not gold! Stem Cells 2007;25:1603-1609.

53 Gruber R, Varga F, Fischer MB, Watzek G: Platelets stimulate proliferation of bone cells: involvement of platelet-derived growth factor, microparticles and membranes. Clin Oral Implants Res 2002;13: 529-535.

54 Graziani F, Ivanovski S, Cei S, Ducci F, Tonetti M, Gabriele M: The in vitro effect of different PRP concentrations on osteoblasts and fibroblasts. Clin Oral Implants Res 2006;17:212-219.

55 Lucarelli E, Beccheroni A, Donati D, Sangiorgi L, Cenacchi A, Del Vento AM, Meotti C, Bertoja AZ, Giardino R, Fornasari PM, Mercuri M, Picci P: Platelet-derived growth factors enhance proliferation of human stromal stem cells. Biomaterials 2003;24:3095-3100.

56 Kilian O, Flesch I, Wenisch S, Taborski B, Jork A, Schnettler R, Jonuleit T: Effects of platelet growth factors on human mesenchymal stem cells and human endothelial cells in vitro. Eur J Med Res 2004;9:337-344.

57 Marx RE, Carlson ER, Eichstaedt RM, Schimmele SR, Strauss JE, Georgeff KR: Platelet-rich plasma: growth factor enhancement for bone grafts. Oral Surg Oral Med Oral Pathol Oral Radiol Endod 1998;85:638-646.

58 Lucarelli E, Fini M, Beccheroni A, Giavaresi G, Di Bella C, Aldini NN, Guzzardella G, Martini L, Cenacchi A, Di Maggio N, Sangiorgi L, Fornasari PM, Mercuri M, Giardino R, Donati D: Stromal stem cells and platelet-rich plasma improve bone allograft integration. Clin Orthop Relat Res 2005;435: 62-68.

59 Kocaoemer A, Kern S, Kluter H, Bieback K: Human AB serum and thrombin-activated plateletrich plasma are suitable alternatives to fetal calf serum for the expansion of mesenchymal stem cells from adipose tissue. Stem Cells 2007;25:1270-1278.

60 Yamaguchi M, Hirayama F, Wakamoto S, Fujihara M, Murahashi H, Sato N, Ikebuchi K, Sawada K, Koike T, Kuwabara M, Azuma H, Ikeda H: Bone marrow stromal cells prepared using $\mathrm{AB}$ serum and bFGF for hematopoietic stem cells expansion. Transfusion 2002;42:921-927.
61 Anselme K, Broux O, Noel B, Bouxin B, Bascoulergue $\mathrm{G}$, Dudermel AF, Bianchi $\mathrm{F}$, Jeanfils J, Hardouin P: In vitro control of human bone marrow stromal cells for bone tissue engineering. Tissue Eng 2002;8:941-953.

62 Le Blanc K, Samuelsson H, Lonnies L, Sundin M Ringden O: Generation of immunosuppressive mesenchymal stem cells in allogeneic human serum. Transplantation 2007:84:1055-1059.

63 Shahdadfar A, Fronsdal K, Haug T, Reinholt FP Brinchmann JE: In vitro expansion of human mesenchymal stem cells: choice of serum is a determinant of cell proliferation, differentiation, gene expression, and transcriptome stability. Stem Cells 2005;23:1357-1366.

64 Gregory CA, Reyes E, Whitney MJ, Spees JL: Enhanced engraftment of mesenchymal stem cells in a cutaneous wound model by culture in allogenic species-specific serum and administration in fibrin constructs. Stem Cells 2006;24:2232-2243.

65 Kratchmarova I, Blagoev B, Haack-Sorensen M, Kassem M, Mann M: Mechanism of divergen growth factor effects in mesenchymal stem cell differentiation. Science 2005;308:1472-1477.

$66 \mathrm{Ng} \mathrm{F}$, Boucher S, Koh S, Sastry KS, Chase L, Lakshmipathy U, Choong C, Yang Z, Vemuri MC, Rao MS, Tanavde V: PDGF, TGF-b and FGF signaling is important for differentiation and growth of mesenchymal stem cells (MSCs): transcriptional profiling can identify markers and signaling pathways important in differentiation of MSC into adipogenic, chondrogenic and osteogenic lineages. Blood 2008(Epub ahead of print)

67 Tsutsumi S, Shimazu A, Miyazaki K, Pan H, Koike C, Yoshida E, Takagishi K, Kato Y: Retention of multilineage differentiation potential of mesenchymal cells during proliferation in response to FGF Biochem Biophys Res Commun 2001;288:413-419.

68 Kogler G, Sensken S, Wernet P: Comparative generation and characterization of pluripotent unrestricted somatic stem cells with mesenchymal stem cells from human cord blood. Exp Hematol 2006; 34:1589-1595.

69 De Boer J, Wang HJ, Van Blitterswijk C: Effects of Wnt signaling on proliferation and differentiation of human mesenchymal stem cells. Tissue Eng 2004; 10:393-401.

70 Ebert R, Ulmer M, Zeck S, Meissner-Weigl J, Schneider D, Stopper H, Schupp N, Kassem M, Jakob F: Selenium supplementation restores the antioxidative capacity and prevents cell damage in bone marrow stromal cells in vitro. Stem Cells 2006; 24:1226-1235.

71 Stolzing A, Coleman N, Scutt A: Glucose-induced replicative senescence in mesenchymal stem cells. Rejuvenation Res 2006;9:31-35

72 Li YM, Schilling T, Benisch P, Zeck S, MeissnerWeigl J, Schneider D, Limbert C, Seufert J, Kassem M, Schutze N, Jakob F, Ebert R: Effects of high glucose on mesenchymal stem cell proliferation and differentiation. Biochem Biophys Res Commun 2007;363:209-215.

73 Sensebe L: Clinical grade production of mesenchymal stem cells. Biomed Mater Eng 2008;18(suppl 1):S3-10.

74 Schallmoser K, Bartmann C, Rohde E, Reinisch A, Kashofer K, Stadelmeyer E, Drexler C, Lanzer G, Linkesch W, Strunk D: Human platelet lysate can replace fetal bovine serum for clinical-scale expansion of functional mesenchymal stromal cells. Transfusion 2007;47:1436-1446. 
75 Gastens MH, Goltry K, Prohaska W, Tschope D, Stratmann B, Lammers D, Kirana S, Gotting C, Kleesiek K: Good manufacturing practice-compliant expansion of marrow-derived stem and progenitor cells for cell therapy. Cell Transplant 2007;16: 685-696.

76 Dennis JE, Esterly K, Awadallah A, Parrish CR, Poynter GM, Goltry KL: Clinical-scale expansion of a mixed population of bone-marrow-derived stem and progenitor cells for potential use in bonetissue regeneration. Stem Cells 2007;25:2575-2582.

77 Baksh D, Zandstra PW, Davies JE: A non-contact suspension culture approach to the culture of osteogenic cells derived from a CD49elow subpopulation of human bone marrow-derived cells. Biotechnol Bioeng 2007;98:1195-1208.

78 Baksh D, Davies JE, Zandstra PW: Adult human bone marrow-derived mesenchymal progenitor cells are capable of adhesion-independent survival and expansion. Exp Hematol 2003;31:723-732.

79 Chen X, Xu H, Wan C, McCaigue M, Li G: Bioreactor expansion of human adult bone marrow-derived mesenchymal stem cells. Stem Cells 2006;24: 2052-2059.

80 Xie Y, Hardouin P, Zhu Z, Tang T, Dai K, Lu J: Three-dimensional flow perfusion culture system for stem cell proliferation inside the critical-size beta-tricalcium phosphate scaffold. Tissue Eng 2006;12:3535-3543.
81 Zhao F, Pathi P, Grayson W, Xing Q, Locke BR, Ma T: Effects of oxygen transport on 3-d human mesenchymal stem cell metabolic activity in perfusion and static cultures: experiments and mathematical model. Biotechnol Prog 2005;21:1269-1280.

82 Rohde E, Schallmoser K, Bartmann C, Reinisch A, Strunk D: GMP-compliant propagation of human multipotent mesenchymal stromal cells; in Gad SC (ed): Pharmaceutical Manufacturing Handbook: Regulations and Quality. Hoboken, NJ, John Wiley and Sons, 2008, pp 97-115.

83 Dominici M, Le Blanc K, Mueller I, Slaper-Cortenbach I, Marini F, Krause D, Deans R, Keating A, Prockop D, Horwitz E: Minimal criteria for defining multipotent mesenchymal stromal cells. The International Society for Cellular Therapy position statement. Cytotherapy 2006;8:315-317.

84 Bruchmuller I, Pirkl E, Herrmann R, Stoermer M, Eichler H, Kluter H, Bugert P: Introduction of a validation concept for a PCR-based Mycoplasma detection assay. Cytotherapy 2006;8:62-69.

85 Guideline on validation of the Limulus amebocyte lysate test as an end-product endotoxin test for human and animal parenteral drugs, biological products, and medical devices. 1987, sections I-IV: http://www.fda.gov/cber/gdlns/lal.pdf.

86 Luria EA, Panasyuk AF, Friedenstein AY: Fibroblast colony formation from monolayer cultures of blood cells. Transfusion 1971;11:345-349.
87 Friedenstein AJ, Deriglasova UF, Kulagina NN, Panasuk AF, Rudakowa SF, Luria EA, Ruadkow IA: Precursors for fibroblasts in different populations of hematopoietic cells as detected by the in vitro colony assay method. Exp Hematol 1974;2: 83-92.

88 Pittenger MF, Martin BJ: Mesenchymal stem cells and their potential as cardiac therapeutics. Circ Res 2004;95:9-20.

89 Delorme B, Chateauvieux S, Charbord P: The concept of mesenchymal stem cells. Regen Med 2006;1: 497-509.

90 Le Blanc K, Tammik L, Sundberg B, Haynesworth SE, Ringden O: Mesenchymal stem cells inhibit and stimulate mixed lymphocyte cultures and mitogenic responses independently of the major histocompatibility complex. Scand J Immunol 2003;57:11-20.

91 Robinson SN, Ng J, Niu T, Yang H, McMannis JD, Karandish S, Kaur I, Fu P, Del Angel M, Messinger R, Flagge F, de Lima M, Decker W, Xing D, Champlin R, Shpall EJ: Superior ex vivo cord blood expansion following co-culture with bone marrow-derived mesenchymal stem cells. Bone Marrow Transplant 2006;37:359-366.

92 Zhang Y, Chai C, Jiang XS, Teoh SH, Leong KW: Co-culture of umbilical cord blood CD34+ cells with human mesenchymal stem cells. Tissue Eng 2006;12:2161-2170. 